\title{
Novel molecular mechanisms involved in hormonal regulation of lactate production in Sertoli cells
}

\author{
Mariana Regueira, Silvana Lucía Artagaveytia, María Noel Galardo, Eliana Herminia Pellizzari, \\ Selva Beatriz Cigorraga, Silvina Beatriz Meroni and María Fernanda Riera \\ Centro de Investigaciones Endocrinológicas 'Dr César Bergadá' (CEDIE/CONICET-FEI-GCBA), Hospital de Niños $R$ \\ Gutiérrez, Gallo 1330, C1425EDF Buenos Aires, Argentina \\ Correspondence should be addressed to M F Riera; Email: friera@cedie.org.ar
}

\begin{abstract}
The aim of the study was to analyze molecular mechanisms involved in FSH and basic fibroblast growth factor (bFGF) regulation of lactate production in rat Sertoli cells. The regulation of the availability of pyruvate, which is converted to lactate, could be a mechanism utilized by hormones to ensure lactate supply to germ cells. On one hand, the regulation of 6-phosphofructo-2-kinase/ fructose-2,6-biphosphatase (PFKFB) expression could result in increased glycolysis, while an increase in pyruvate availability may also result from a lower conversion to acetyl-CoA by negative regulation of pyruvate dehydrogenase complex (PDC) activity by phosphorylation. Sertoli cell cultures obtained from 20-day-old rats were used. Stimulation of the cultures with FSH or bFGF showed that FSH increases Pfkfb1 and Pfkfb3 expression while bFGF increases Pfkfb1 mRNA levels. Additionally, we observed that FSH-stimulated lactate production was inhibited in the presence of a PFKFB3 inhibitor, revealing the physiological relevance of this mechanism. As for the regulation of PDC, analysis of pyruvate dehydrogenase kinase (Pdk) expression showed that FSH increases Pdk3 and decreases Pdk4 mRNA levels while bFGF increases the expression of all Pdks. In addition, we showed that bFGF increases phosphorylated PDC levels and that bFGF-stimulated lactate production is partially inhibited in the presence of a PDK inhibitor. Altogether, these results add new information regarding novel molecular mechanisms involved in hormonal regulation of lactate production in Sertoli cells. Considering that lactate is essential for the production of energy in spermatocytes and spermatids, these mechanisms might be relevant in maintaining spermatogenesis and male fertility.

Reproduction (2015) $150311-321$
\end{abstract}

\section{Introduction}

Sertoli cells are essential for the normal development of spermatogenesis, with the follicle-stimulating hormone (FSH) playing a pivotal role in the regulation of its function. Sertoli cells are also under autocrine and paracrine control, which result from multiple and complex interactions between the different testicular cells (Gnessi et al. 1997). Among the peptides involved in paracrine control, basic fibroblast growth factor (bFGF), which is mainly produced by germ cells, has been observed to regulate many Sertoli cell functions. It has been shown that in these cells bFGF modulates transferrin release (Han et al. 1993), plasminogen activator inhibitor-1, CFos and Jun B expression (Smith et al. 1989, Le Magueresse-Battistoni et al. 1998) and estradiol, glutathione and lactate production (Schteingart et al. 1999, Riera et al. 2002, Gualtieri et al. 2009).

Carbohydrate metabolism in the testis presents some unique characteristics. Sertoli cells actively metabolize glucose but the majority of it is converted to lactate
(Robinson \& Fritz 1981, Grootegoed et al. 1986). On the other hand, spermatocytes and spermatids are unable to use glucose for their energy metabolism and prefer lactate as an energy source (Jutte et al. 1981, Mita \& Hall 1982). These observations have led to the conclusion that one of the most important Sertoli cell nurse functions is to provide lactate for the production of energy in germ cells (Boussouar \& Benahmed 2004). In this context, the mechanisms that regulate lactate production in Sertoli cells are relevant to the maintenance of spermatogenesis and male fertility.

It has been previously demonstrated that $\mathrm{FSH}$ and bFGF increase lactate production in Sertoli cells and that several molecular mechanisms are involved (Mita et al. 1982, Riera et al. 2001, 2002, Meroni et al. 2002, Galardo et al. 2008). Among the mechanisms that may contribute to increased lactate production by $\mathrm{FSH}$ and bFGF, the regulation of pyruvate availability has not yet been analyzed. Such an increase in pyruvate availability may result from an augmentation in the glycolytic flux and/or from a lower conversion to acetyl-CoA, caused 
by the negative regulation of pyruvate dehydrogenase complex (PDC) activity.

6-phosphofructo-1-kinase (PFK1) is the enzyme that catalyzes the major regulatory step in the glycolytic pathway. Several allosteric sites are present in PFK1 that turn on and off the enzymatic activity. Among the allosteric regulators, fructose 2,6-biphosphate (Fru-2,6-P2) is the most potent activator of PFK1 and undoubtedly increases glycolytic flux (Hue \& Rider 1987). The levels of Fru-2,6-P2 are regulated by the bifunctional enzyme 6-phosphofructo-2-kinase/fructose-2,6-biphosphatase (PFKFB), which catalyzes both synthesis and degradation of Fru-2,6-P2. In mammals, the isoforms of PFKFB are encoded by four separate genes, Pfkfb1-4, which are characterized by their tissue expression pattern and by the particular ratio of kinase to phosphatase activity (Rider et al. 2004). It has been known for a long time that phosphorylation plays a pivotal role in the regulation of PFKFB activity (Hue \& Rider 1987). More recently, it has been demonstrated that upregulation of the expression of different isoforms of PFKFBs results in an increase of glycolytic flux in different cell types (Marsin et al. 2002, Moon et al. 2011, Novellasdemunt et al. 2012). In the testis, it has been observed that PFKFB3 is expressed in Sertoli cells and that PFKFB4 is present in germ cells (Gómez et al. 2009). The expression of others PFKFBs and the possible hormonal regulation of their expression have not yet been studied in Sertoli cells.

As previously mentioned, another mechanism contributing to increased pyruvate availability, which in turn leads to increased lactate production, is a decreased conversion of the ketoacid into acetyl-CoA. The PDC is responsible for the irreversible oxidative decarboxylation of pyruvate to acetyl-CoA. As a matter of fact, PDC links glycolysis with the tricarboxylic acid cycle and, like many other rate-limiting enzymes, it is tightly regulated. A reversible phosphorylation/dephosphorylation cycle is the mechanism responsible for the regulation of PDC activity (Holness \& Sugden 2003). Phosphorylation of PDC by pyruvate dehydrogenase kinase (PDK) causes inactivation of the complex. Such inhibition can only be reversed by pyruvate dehydrogenase phosphatase (PDP) that removes phosphate from PDC. In this context, the relative activities of PDKs and PDPs will determine the proportion of PDC in its active form and consequently the levels of pyruvate committed to the tricarboxylic acid cycle (Kolobova et al. 2001, Sugden \& Holness 2006). To date, four isoforms of PDK (PDK1-4) and two isoforms of PDP (PDP1-2) have been identified. These isoforms display unique tissue distribution and varied kinetic and regulatory properties (Bowker-Kinley et al. 1998, Huang et al. 1998). We have recently observed that different isoforms of PDKs and PDPs are present in Sertoli cells (Regueira et al. 2014) but their possible hormonal regulation, particularly by FSH and bFGF, has not yet been analyzed.

The aim of the present study was to investigate whether FSH and bFGF can regulate the expression of
Pfkfbs and/or the levels of phosphorylated PDC by means of Pdks and Pdps expression. A role for these molecular mechanisms in lactate production in Sertoli cells in order to ensure nutrient supply for germ cell development is postulated.

\section{Materials and methods}

Twenty-day-old Sprague-Dawley rats were obtained from an animal care unit (Animal Care Laboratory, Instituto de Biología y Medicina Experimental, Buenos Aires, Argentina). Animals were killed by $\mathrm{CO}_{2}$ asphyxiation according to protocols for animal laboratory use following the principles and procedures outlined in the National Institute of Health Guide for Care and Use of Laboratory Animals. The protocol was approved by the Ethical Commitee from the Instituto de Biología y Medicina Experimental (Ref.: CE 011/2015, IByME).

Human recombinant bFGF was purchased from Invitrogen (Life Technologies Argentina). Ovine FSH (NIH-oFSH-S-16) was obtained from the National Hormone and Pituitary Program, National Institute of Diabetes and Digestive and Kidney Diseases (Bethesda, MD, USA). PFKFB3 inhibitor, 3PO, was purchased from Calbiochem (EMD Millipore Corporation, Chicago, IL, USA). Tissue culture media, dichloroacetate (DCA) and all other drugs and reagents were purchased from Sigma-Aldrich (St Louis, MO, USA).

\section{Sertoli cell isolation and culture}

Sertoli cells from 20-day-old Sprague-Dawley rats were isolated as previously described (Meroni et al. 2002). Briefly, decapsulated testes were digested with $0.1 \% \mathrm{w} / \mathrm{v}$ collagenase and $0.006 \% \mathrm{w} / \mathrm{v}$ soybean trypsin inhibitor in Hanks' balanced salt solution for $5 \mathrm{~min}$ at room temperature. Seminiferous tubules were saved, cut and submitted to 1 M glycine-2 mM EDTA ( $\mathrm{pH}$ 7.4) treatment to remove peritubular cells. The washed tubular pellet was then digested again with collagenase for $10 \mathrm{~min}$ at room temperature to remove germinal cells. The Sertoli cell suspension, collected by sedimentation, was resuspended in culture medium which consisted of a 1:1 mixture of Ham's F-12 and DMEM, supplemented with $20 \mathrm{mM}$ HEPES, $100 \mathrm{IU} / \mathrm{ml}$ penicillin, $2.5 \mu \mathrm{g} / \mathrm{ml}$ amphotericin B, $1.2 \mathrm{mg} / \mathrm{ml}$ sodium bicarbonate, $10 \mu \mathrm{g} /$ $\mathrm{ml}$ transferrin, $5 \mu \mathrm{g} / \mathrm{ml}$ insulin, $5 \mu \mathrm{g} / \mathrm{ml}$ vitamin $\mathrm{E}$ and $4 \mathrm{ng} / \mathrm{ml}$ hydrocortisone. Sertoli cells were cultured in $6-$, 24- or 96 -multiwell plates $\left(5 \mu \mathrm{g} \mathrm{DNA} / \mathrm{cm}^{2}\right)$ at $34{ }^{\circ} \mathrm{C}$ in a mixture of $5 \% \mathrm{CO}_{2}: 95 \%$ air.

No myoid cell contamination was revealed in the cultures when an immunoperoxidase technique was applied to Sertoli cell cultures using a specific antiserum to smooth muscle $\alpha$ actin. Remaining cell contaminants were of germ cell origin and this contamination was 
below $5 \%$ after $48 \mathrm{~h}$ in culture as examined by phase contrast microscopy.

\section{Culture conditions}

Sertoli cells were allowed to attach for $48 \mathrm{~h}$ in the presence of insulin and medium was replaced at this time with fresh medium without insulin. Cells incubated for 24 - or 48 -h with FSH (100 ng/ml) or bFGF (30 ng/ml) were used to evaluate Pfkfbs, Pdks and Pdps mRNA levels and to determine phosphorylated PDC (P-PDC) protein levels. To evaluate the role of PFKFB3, cells were incubated in the absence or presence of variable doses of $3 \mathrm{PO}$ for $48 \mathrm{~h}$. The conditioned media were used to evaluate lactate production. To evaluate the role of PDKs, cells were incubated in the absence or presence of variable doses of DCA for $48 \mathrm{~h}$. The cells and the conditioned media were used to evaluate P-PDC levels and lactate production respectively.

\section{RT-PCR}

Testicular tissue and purified Sertoli were utilized to isolate total RNA using TRI Reagent (Sigma-Aldrich) according to the manufacturer's recommendations. The amount of RNA was estimated by spectrophotometry at $260 \mathrm{~nm}$. RT was performed on $2 \mu \mathrm{g}$ RNA at $42{ }^{\circ} \mathrm{C}$ for 50 min with a mixture containing $200 \mathrm{U}$ MMLV reverse transcriptase enzyme, $125 \mathrm{ng}$ random primers and $0.5 \mathrm{mM}$ dNTP Mix (Invitrogen). The cDNAs enconding Pfkfb1-3, Pdk1-4 and Pdp1-2 were amplified from $1 \mu$ of the cDNA reaction mixture using specific gene primers (Table 1). PCR was performed with GoTaq DNA polymerase (Promega Corporation) under the following conditions: initial denaturation at $94{ }^{\circ} \mathrm{C}$ for $5 \mathrm{~min}$; 35 cycles of $94{ }^{\circ} \mathrm{C}$ for $30 \mathrm{~s} ; 60^{\circ} \mathrm{C}$ for $30 \mathrm{~s}$ and extension at
$72{ }^{\circ} \mathrm{C}$ for $50 \mathrm{~s}$ followed by $10 \mathrm{~min}$ at $72{ }^{\circ} \mathrm{C}$. The PCR products were resolved by $2 \% \mathrm{w} / \mathrm{v}$ agarose gel and stained with ethidium bromide.

\section{Real-time PCR}

Total RNA was isolated from Sertoli cells cultured in sixmultiwell plates with TRI Reagent (Sigma-Aldrich) according to the manufacturer's recommendations. The amount of RNA was estimated by spectrophotometry at $260 \mathrm{~nm}$. RT was performed as mentioned in RT-PCR. Real-time PCR (RT-qPCR) was performed by a StepOnePlusTM Real-Time PCR System (Applied Biosystems). Amplification was carried out as recommended by the manufacturer: $25 \mu \mathrm{l}$ reaction mixture containing $12.5 \mu \mathrm{l}$ of SYBR Green PCR Master mix (Applied Biosystems), the appropriate primer concentration and $1 \mu \mathrm{l}$ of cDNA. Table 1 shows the specific primers used to analyze Pfkfb1-3, Pdk1-4, Pdp1-2 and hypoxanthine phosphoribosyltransferase 1 (Hprt1) expression. The relative cDNA concentrations were established by a standard curve using sequential dilutions of a cDNA sample. Hprt1 was used as reference gene. The amplification program included the initial denaturation step at $95^{\circ} \mathrm{C}$ for $10 \mathrm{~min}, 40$ cycles of denaturation at $95^{\circ} \mathrm{C}$ for $15 \mathrm{~s}$, and annealing and extension at $60^{\circ} \mathrm{C}$ for $1 \mathrm{~min}$. Fluorescence was measured at the end of each extension step. After amplification, melting curves were acquired and used to determine the specificity of PCR products. The comparative $\Delta \Delta C$ t method was used to calculate relative gene expression.

\section{Western blot analysis}

Cells cultured in six-multiwell plates were washed once with PBS at room temperature. Then, $200 \mu \mathrm{l}$ of PBS

Table 1 Rat-specific primers sets for RT-PCR analysis.

\begin{tabular}{|c|c|c|}
\hline Gene & Primer sequence & Accession number \\
\hline \multirow[t]{2}{*}{$P d k 1$} & FWD: 5'-TCCAGGGAGACCTAAAGCTG-3' & NM_053826.2 \\
\hline & REV: 5'-CGTGGTTGGTTCTGTAATGC-3' & \\
\hline \multirow[t]{2}{*}{$P d k 2$} & FWD: 5'-GACCCAGTCTCCAACCAGAAC-3' & NM_030872.1 \\
\hline & REV: 5'-GGGATCAATGCTGCCAATGTG-3' & \\
\hline \multirow[t]{2}{*}{$P d k 3$} & FWD: 5'-GTCGCCGCTCTCTATCAAAC-3' & NM_01106581.1 \\
\hline & REV: 5'-AGCCAGTCGCACAGGAAG-3' & \\
\hline \multirow{2}{*}{$P d k 4$} & FWD: 5'-CGAAGATGCCTTTGAGTGTG-3' & NM_053551.1 \\
\hline & REV: 5'-TGGTGAAGGTGTGAAGGAAC-3' & \\
\hline \multirow{2}{*}{ Pdp1 } & FWD: 5'-CAGGAGAATGTGTGTGTGTCC-3' & NM_019372 \\
\hline & REV: 5'-TGGCATCAGAGAACAGTGGTAG-3' & \\
\hline \multirow[t]{2}{*}{ Pdp2 } & FWD: 5'-AGAGGATTCGCCCAGTGTC-3' & NM_145091.4 \\
\hline & REV: 5'-AAGTGGAGGTGGAGTGTTTTTTC-3' & \\
\hline \multirow[t]{2}{*}{ Pfkfb1 } & FWD: 5'-CCATTACTGAGCCCTTTTCAAG-3' & NM_012621.4 \\
\hline & REV: 5'-TGCTACGGACTTCTTCACTGG-3' & \\
\hline \multirow[t]{2}{*}{ Pfkfb2 } & FWD:5'-GTGGTGGCAGTGTTCAAGAG-3' & NM_01033964.1 \\
\hline & REV: 5'-TTCCCCGTCCGTCTTCTATC-3' & \\
\hline \multirow{2}{*}{ Pfkfb3 } & FWD: 5'-CACCCTTCCTGTCCTTTGTTC-3' & NM_057135 \\
\hline & REV: 5'-GCATCTTCGTTGCTGTATTCG-3' & \\
\hline \multirow[t]{2}{*}{ Hprt1 } & FWD: 5'-AGTTCTTTGCTGACCTGCTG-3' & NM_012583.2 \\
\hline & REV: 5'-TTTATGTCCCCCGTTGACTG-3' & \\
\hline
\end{tabular}


containing $2 \mu \mathrm{l}$ of protease inhibitor cocktail (P-8340; Sigma-Aldrich), $1 \mathrm{mM} \mathrm{NaF}, 1 \mathrm{mM}$ EGTA, 1 mM EDTA, $50 \mathrm{nM}$ okadaic acid and 2 mM PMSF was added to each well. Cells collected by scrapping were then placed on ice and disrupted by ultrasonic irradiation. For western blot analysis, $200 \mu$ l of $2 \times$ Laemmli buffer $(4 \% \mathrm{w} / \mathrm{v}$ SDS, $20 \% \mathrm{v} / \mathrm{v}$ glycerol, $10 \% \mathrm{v} / \mathrm{v} 2$-mercaptoethanol, $0.004 \%$ $\mathrm{w} / \mathrm{v}$ bromophenol blue, and $0.125 \mathrm{M}$ Tris- $\mathrm{HCl}, \mathrm{pH} 6.8$ ) was added and thoroughly mixed. Samples were immersed in boiling water bath for $5 \mathrm{~min}$ and then immediately settled on ice. Proteins ( $40 \mu \mathrm{g}$ in each lane) were resolved in $10 \%$ SDS-PAGE (10\% acrylamide/ bisacrylamide for the resolving gel and $4.3 \%$ acrylamide/bisacrylamide for the stacking gel) in a Mini Protean 3 cell (Bio-Rad, Hercules, CA, USA). After SDS-PAGE, gels were electrotrasferred at $100 \mathrm{~V}$ for $60 \mathrm{~min}$ onto PVDF membranes (Hybond-P, GE Healthcare Life Sciences, Piscataway, NJ, USA) using a Mini Trans-blot cell (Bio-Rad). Membranes were probed with specific antibodies that recognized the phosphorylated form of PDC (P-PDC) (Pyruvate dehydrogenase E1- $\alpha$ subunit (P-Ser293) antibody, Novus Biologicals, Littleton, CO, USA) or total AKT (T-AKT) (AKT antibody, Cell Signaling Technology, Inc., Danvers, MA, USA). A 1:4000 (P-PDC) or 1:1000 (T-AKT) dilutions of primary antibodies were used. Levels of T-AKT were used as loading control. For chemiluminescent detection of the blots a commercial kit was used (Cell Signaling Technology). The intensities of the autoradiographic bands were estimated by densitometry scanning using NIH Image Software (Scion Corporation, Frederick, MD, USA).

\section{Lactate determination}

Conditioned media obtain from cells cultured in 24-multiwell plates were used to determine lactate production. Lactate was measured by a standard method involving conversion of $\mathrm{NAD}^{+}$to $\mathrm{NADH}$. The amount of NADH was determined as the rate of increase of absorbance at $340 \mathrm{~nm}$. A commercial kit from SigmaAldrich was used.

\section{Other assays}

A cell viability test was performed in cells cultured on 96-multiwell using a commercial kit (CellTiter 96 Aqueous Non-Radioactive Cell Proliferation Assay; Promega Corporation). DNA was determined as described previously (Riera et al. 2002). Protein content was determined by Lowry's assay.

\section{Statistical analysis}

All experiments were run in triplicates and repeated three to four times. Results are expressed as means \pm s.D.
One way ANOVA and post hoc analysis using TukeyKramer's multiple comparisons test were performed using GraphPad InSat version 3.00 for Windows 95 (GraphPad Software, San Diego, CA, USA). P values $<0.05$ were considered statistically significant.
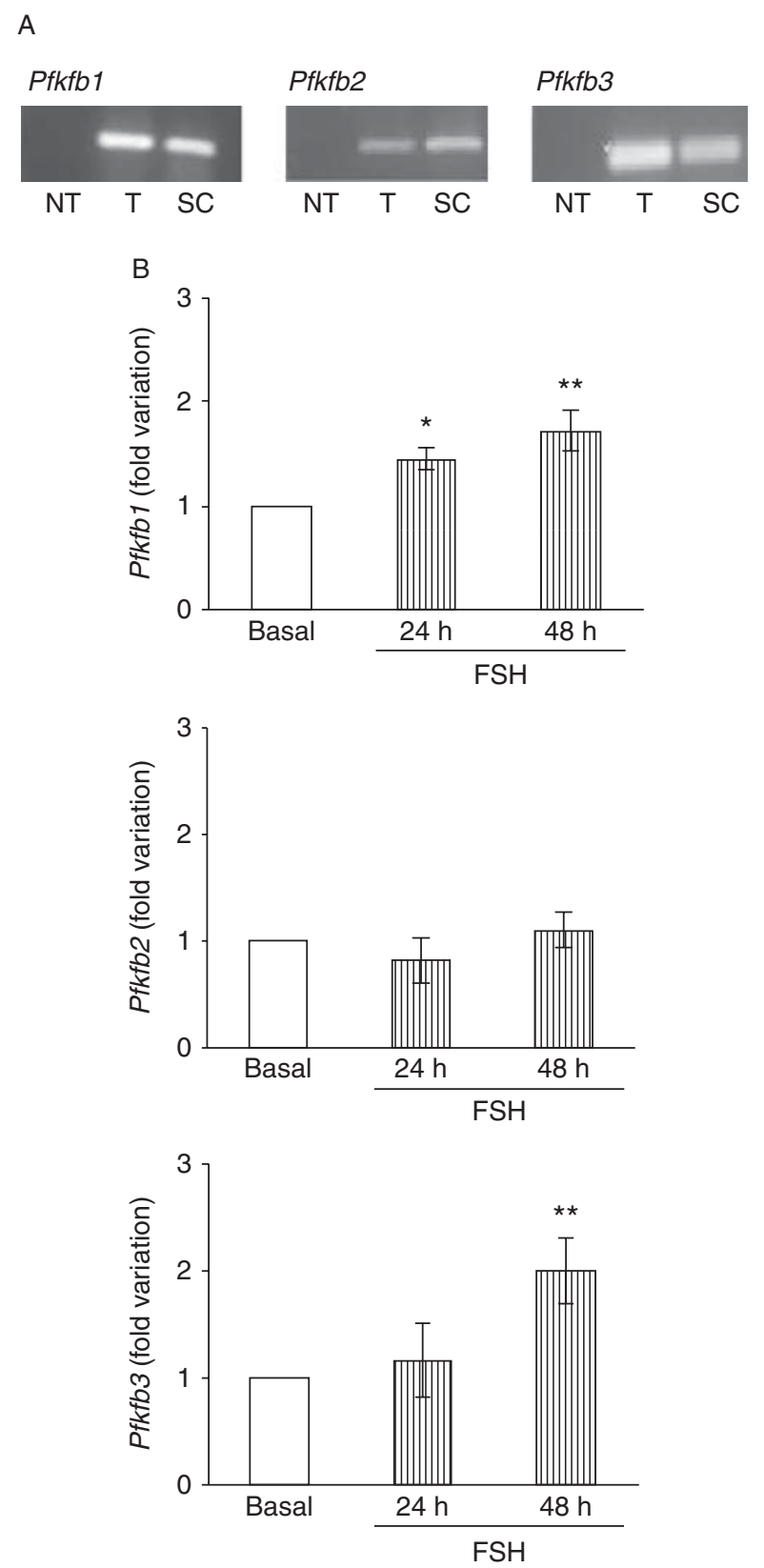

Figure 1 Effect of FSH on Pfkfbs mRNA levels in Sertoli cells. (A) Characterization of Pfkfb1-3 expression in Sertoli cells was performed. Total RNA of rat testis (T) or Sertoli cells (SC) were extracted, analyzed by RT-PCR and visualized by ethidium bromide staining. NT indicates no template control. (B) Sertoli cells were incubated for variable periods of time ( 24 and $48 \mathrm{~h}$ ) with $100 \mathrm{ng} / \mathrm{ml} \mathrm{FSH}$. Total cellular RNA was then extracted and RT-qPCRs for Pfkfb1-3 were performed. The comparative $\Delta \Delta C$ method was used to calculate relative gene expression. Results are expressed as mean \pm S.D. of four independent experiments. ${ }^{*} P<0.01 ;{ }^{*} P<0.05$ vs basal. 


\section{Results}

\section{Regulation of Pfkfb1-Pfkfb3 mRNA levels by FSH and $b F G F$}

RT-PCR analysis was used to evaluate the expression of three isoforms of PFKFBs, Pfkfb1-Pfkfb3, in rat Sertoli cells. Figure 1A showed that Sertoli cells express Pfkfb1, $P f k f b 2$ and $P f k f b 3$. To evaluate hormonal regulation of their expression, Sertoli cell cultures were stimulated for 24- or 48-h with FSH (100 ng/ml) or bFGF $(30 \mathrm{ng} / \mathrm{ml})$, doses that have been shown to promote a maximal response in lactate production (Riera et al. 2001, 2002). Figure 1B shows that FSH increased Pfkfb1 and Pfkfb3 and did not modify Pfkfb2 mRNA levels. Figure 2 shows that bFGF increased $P f k f b 1$ mRNA levels and did not modify Pfkfb2 or Pfkfb3 expression.

\section{Participation of PFKFB3 in FSH-stimulated lactate production}

To analyze a possible role of PFKFB3 activity in the stimulatory effect of FSH on lactate production, cells were incubated with $\mathrm{FSH}(100 \mathrm{ng} / \mathrm{ml})$ for $48 \mathrm{~h}$ in the absence or presence of 3PO, a specific PFKFB3 inhibitor. Figure 3 shows that $3 \mathrm{PO}$ decreased $\mathrm{FSH}$-stimulated lactate production while this inhibitor did not modify lactate secretion under basal experimental conditions. A cell viability test performed at the end of the 48-h incubation period showed that $3 \mathrm{PO}$ had no effect on cell viability (Table 2).

\section{Regulation of Pdks and Pdps mRNA levels by FSH and $b F G F$}

RT-PCR analysis was used to evaluate the expression of Pdks (Pdk1-Pdk4) and Pdps (Pdp1-Pdp2) in Sertoli cells. Figure 4A shows that Sertoli cells express all isoforms of $P d k s$ and Pdps. We then evaluated if FSH and bFGF were able to regulate their expression. With that in mind, Sertoli cell cultures were stimulated for 24- or 48-h with FSH $(100 \mathrm{ng} / \mathrm{ml})$ or bFGF $(30 \mathrm{ng} / \mathrm{ml})$. Figure 4B shows that FSH increased $P d k 3$, decreased $P d k 4$ and did not modify Pdk1 and Pdk2 mRNA levels. Additionally, Fig. 4C shows that FSH did not modify Pdp1 or Pdp2 mRNA levels. On the other hand, Fig. 5A and B respectively show that bFGF increased mRNA levels of all Pdks isoforms and did not modify Pdp1 or Pdp2 mRNA levels.

\section{Regulation of P-PDC levels by FSH and bFGF}

Considering that FSH and bFGF induced a differential regulation of Pdks expression, we decided to analyze a possible effect of these hormones on the levels of phosphorylated PDC. For this purpose, Sertoli cell cultures were stimulated for 24- or 48-h with FSH $(100 \mathrm{ng} / \mathrm{ml})$ or bFGF $(30 \mathrm{ng} / \mathrm{ml})$ and the levels of P-PDC
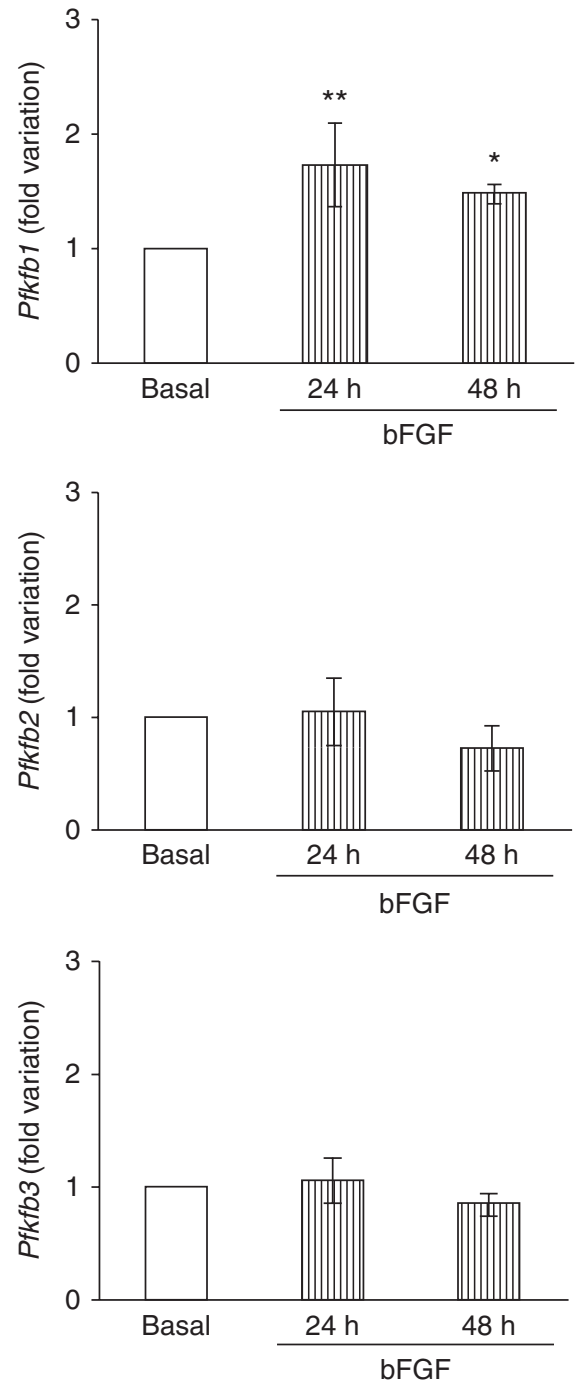

Figure 2 Effect of bFGF on Pfkfbs mRNA levels in Sertoli cells. Sertoli cells were incubated for variable periods of time (24 and $48 \mathrm{~h}$ ) with $30 \mathrm{ng} / \mathrm{ml}$ bFGF. Total cellular RNA was then extracted and RT-qPCRs for Pfkfb1-3 were performed. The comparative $\Delta \Delta C$ t method was used to calculate relative gene expression. Results are expressed as mean \pm s.D. of four independent experiments. ${ }^{*} P<0.01 ;{ }^{*} P<0.05$ vs basal.

were analyzed by western blot. Figure 6 shows that bFGF produced an increase in P-PDC levels and that FSH did not modify them.

\section{Participation of PDKs in bFGF-stimulated lactate production}

The observed concomitant increase in Pdks expression and P-PDC levels promoted by bFGF led us to examine the possible role of PDK activity in the increase in lactate production elicited by this hormone. To achieve this goal, cells were incubated with bFGF $(30 \mathrm{ng} / \mathrm{ml})$ for $48 \mathrm{~h}$ in the absence or presence of the PDK inhibitor, DCA. Figure 7 shows that DCA $(10 \mathrm{mM})$ partially decreased 


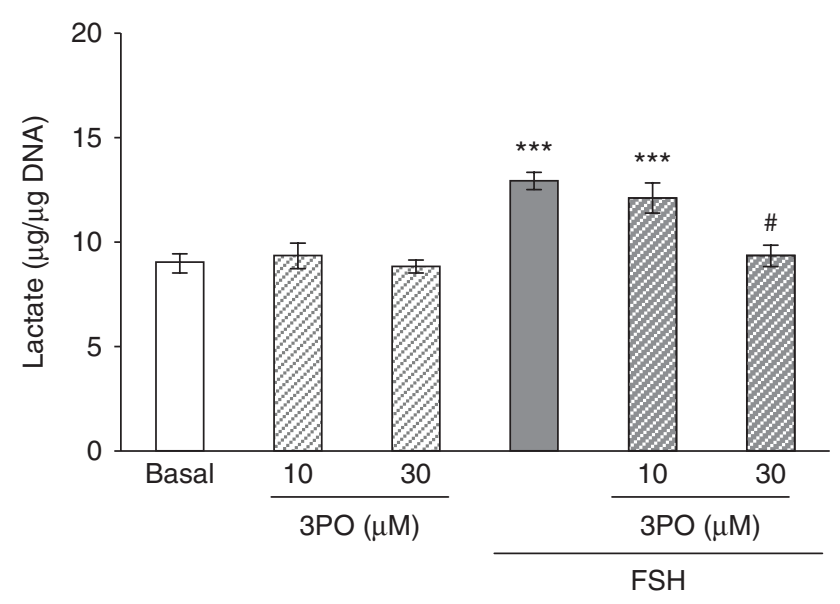

Figure 3 Effect of $3 \mathrm{PO}$ on FSH-stimulated lactate production. Sertoli cells were maintained under basal conditions or incubated for $48 \mathrm{~h}$ with $100 \mathrm{ng} / \mathrm{ml} \mathrm{FSH}$ in the absence or presence of $3 \mathrm{PO}(10 \mu \mathrm{M}$ or $30 \mu \mathrm{M})$, a PFKFB3 inhibitor. Lactate was determined in the 48-h conditioned media. Results are expressed as mean \pm s.D. of triplicate incubations in one representative experiment out of three ${ }^{* * *} P<0.001$ vs basal; ${ }^{\sharp} P<0.001$ vs FSH).

bFGF stimulation of lactate production. DCA did not modify lactate secretion under basal experimental conditions. A cell viability test performed at the end of the 48-h incubation period showed that DCA had no effect on cell viability (Table 2).

\section{Discussion}

The process of spermatogenesis and consequently male fertility are dependent upon the somatic cells that are present in the testis. Although, Leydig cells are essential because of androgen production, Sertoli cells are absolutely necessary in order to provide an adequate and protected environment within the seminiferous tubules. Germ cells situated beyond the blood testis barrier need to rely on Sertoli cell production of factors that fuel their metabolism. In this respect, it has been shown that lactate is the final product of glycolysis in Sertoli cells and that this metabolite is used by germ cells as an energy substrate. In addition to its energetic function, Erkkilä et al. (2002) have shown that lactate inhibits male germ cell apoptosis in human testis and they have proposed that this metabolite may be regarded as a potential compound for optimizing in vitro methods involving male germ cells for assisted reproduction. Furthermore, it has been observed that lactate regulates the expression of genes involved in its own metabolism in cultured rat germ cells (Galardo et al. 2014). The importance of lactate for normal spermatogenesis was highlighted in a report showing that spermatogenesis in adult cryptorchid testis is improved by intratesticular infusion of lactate (Courtens \& Plöen 1999). Altogether, these data suggest that the provision of adequate levels of lactate is a key Sertoli cell function regarding germ cell development.

As mentioned in the introduction, it has been previously shown that FSH and bFGF increase lactate production by regulating several molecular mechanisms in Sertoli cells; among them, glucose transport mediated by the glucose transporter 1 , lactate dehydrogenase (LDH) activity and subunit A of LDH ( $L d h A)$ expression (Riera et al. 2001, 2002, Meroni et al. 2002, Galardo et al. 2008). In the present study we intended to unravel additional molecular mechanisms that may be involved in the hormonal regulation of Sertoli cell lactate production.

It has been known for quite a long time that cancer cells present a characteristic metabolism. In this context, Warburg's studies (Warburg et al. 1927) have shown that glucose metabolism results in a high lactate accumulation, despite adequate oxygen availability. This metabolic pattern, known as the 'Warburg effect', is commonly associated with malignant transformation and is characterized by high glycolytic rates associated with reduced mitochondrial oxidation. While looking for mechanisms that may be participating in the Warburg effect, stimulation of glycolysis and inhibition of the conversion of pyruvate to acetyl-CoA mediated by PDC inactivation have been demonstrated (Chesney 2006, Lu et al. 2008, McFate et al. 2008, Newington et al. 2011). Even though Sertoli cells do not proliferate after puberty, these cells in the testis present similar metabolic characteristics to those observed in cancer cells. Consequently, Sertoli cells have been recently proposed as a useful model to revisit the 'Warburg effect' (Oliveira et al. 2015).

It has been previously shown that several molecular mechanisms participate in the hormonal regulation of lactate production; however, no experimental evidence for the hormonal regulation of glycolytic flux and/or PDC activity in Sertoli cells has been obtained so far. It is also well known that glycolysis is regulated by slowing down or speeding up certain steps in the pathway. PFK1 catalyzes the tightly controlled ratelimiting step in glycolysis. The bifunctional enzyme

Table 2 Effect of $3 \mathrm{PO}$ and DCA on Sertoli cell viability. Sertoli cells were incubated without (Basal), with 3PO (10 or $30 \mu \mathrm{M})$ or DCA (1 or $10 \mathrm{mM}$ ) for $48 \mathrm{~h}$. The cell viability assay was performed after this incubation period. Data are expressed as a percentage of basal conditions and are presented as mean \pm s.D. of quadruplicate incubations in one representative experiment out of three.

\begin{tabular}{lc}
\hline & Cell viability $(\%$ of Basal) \\
\hline Basal & 100 \\
3 PO $(10 \mu \mathrm{M})$ & $103 \pm 11$ \\
$3 P O(30 \mu \mathrm{M})$ & $109 \pm 12$ \\
DCA $1 \mathrm{mM}$ & $98 \pm 11$ \\
DCA $10 \mathrm{mM}$ & $92 \pm 9$ \\
\hline
\end{tabular}

No statistically significant differences were found. 


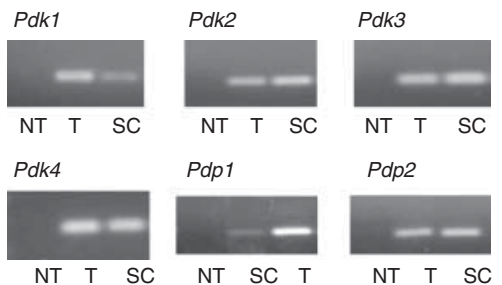

B
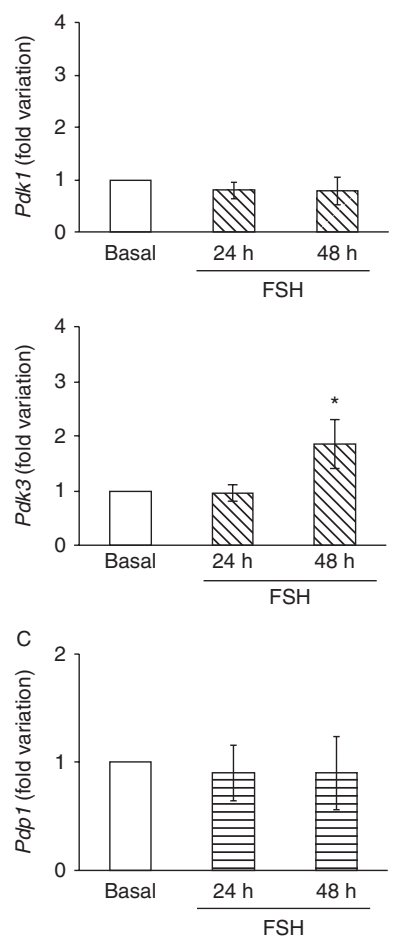
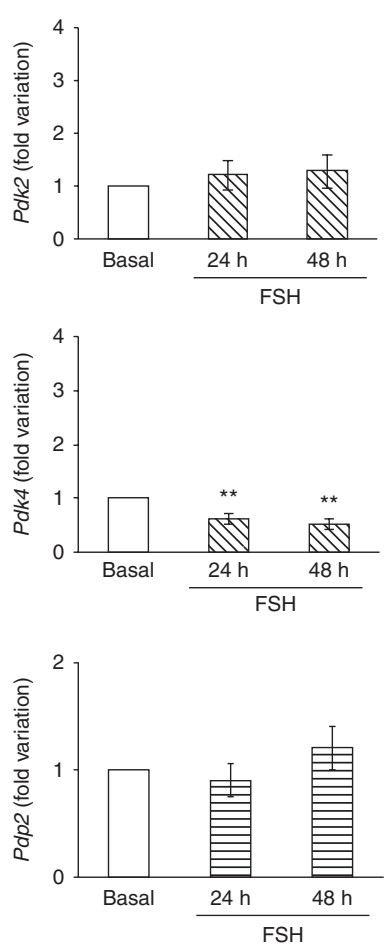

Figure 4 Effect of FSH on Pdks and Pdps mRNA levels in Sertoli cells. (A) Characterization of $P d k 1-4$ and $P d p 1-2$ expression in Sertoli cells was performed. Total RNA of rat testis (T) or Sertoli cells (SC) were extracted, analyzed by RT-PCR and visualized by ethidium bromide staining. NT indicates no template control. (B and C) Sertoli cells were incubated for variable periods of time (24 and $48 \mathrm{~h}$ ) with $100 \mathrm{ng} / \mathrm{ml}$ FSH. Total cellular RNA was then extracted and RT-qPCRs were performed. The comparative $\Delta \Delta C$ t method was used to calculate relative gene expression. Results, $P d k 1-P d k 4$ (B) and $P d p 1$ and $P d p 2$ (C), are expressed as mean \pm s.D. of four independent experiments. ${ }^{* *} P<0.01 ; * P<0.05$ vs basal.

PFKFB catalyzes the production of Fru-2,6-P2, a potent allosteric activator of PFK1. In the present study, we evaluated Pfkfbs isoform expression and their possible hormonal regulation in Sertoli cells. Our results show that Sertoli cells express Pfkfb1, Pfkfb2 and Pfkfb3 isoforms. Additionally, FSH increases Pfkfb1 and Pfkfb3 mRNA levels and bFGF increases the expression of $P f k f b 1$. The relative kinase to phosphatase activities vary among the different PFKFB isoenzymes (Rider et al. 2004). In this context, it has been shown that PFKFB1 has similar kinase and phosphatase activities while PFKFB3 has a 100-fold higher kinase than phosphatase activity, indicating that this isoform mainly acts as a kinase that serves to maintain elevated Fru-2,6-P2 levels (Sakakibara et al. 1997, Ros \& Schulze 2013). In this respect, it has been demonstrated that up-regulation of Pfkfb3 expression is accompanied by increments in glycolytic flux and also in lactate production in different cell types (Marsin et al. 2002, Atsumi et al. 2005, Ando et al. 2010). The physiological relevance of $P f k f b 3$ regulation by $\mathrm{FSH}$ was revealed by the observation that $3 \mathrm{PO}$, a specific PFKFB3 inhibitor, inhibits FSH-stimulated lactate production.

As mentioned in the introduction, PDKs, which phosphorylate and inhibit PDC, and PDPs, which dephosphorylate and activate the complex, participate in the regulation of PDC activity. Our results show that Sertoli cells express all isoforms of Pdks (Pdk1-4) and Pdps (Pdp1-2). It has been postulated that a distinct tissue-specific expression of PDKs and PDPs isoforms evolved to satisfy tissue-specific metabolic requirements (Gudi et al. 1995, Rowles et al. 1996, Bowker-Kinley et al. 1998). PDC complex has three specific serine residues (Ser-293 (site1); Ser300 (site2); Ser232 (site 3))
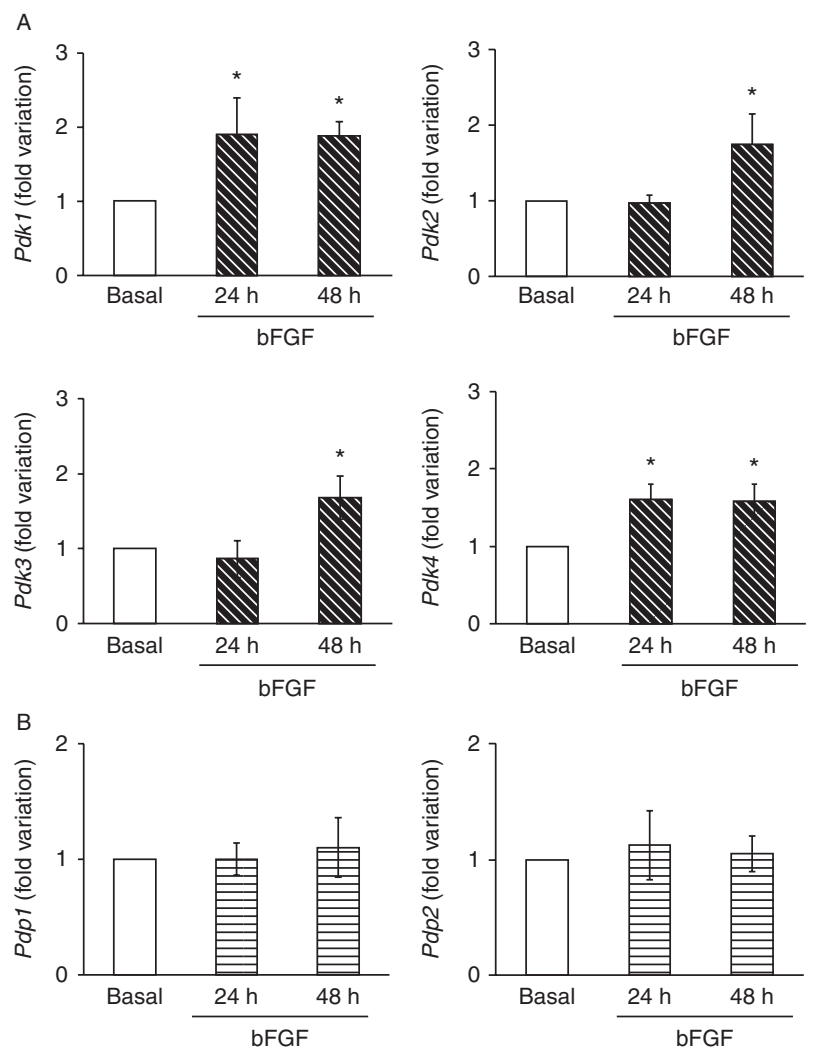

Figure 5 Effect of bFGF on Pdks and Pdps mRNA levels in Sertoli cells. Sertoli cells were incubated for variable periods of time (24 and $48 \mathrm{~h}$ ) with $30 \mathrm{ng} / \mathrm{ml}$ bFGF. Total cellular RNA was then extracted and RT-qPCRs for Pdk1-Pdk4 (A) and for Pdp1 and Pdp2 (B) were performed. The comparative $\Delta \Delta C$ t method was used to calculate relative gene expression. Results are expressed as mean \pm s.D. of four independent experiments. ${ }^{*} P<0.05$ vs basal. 

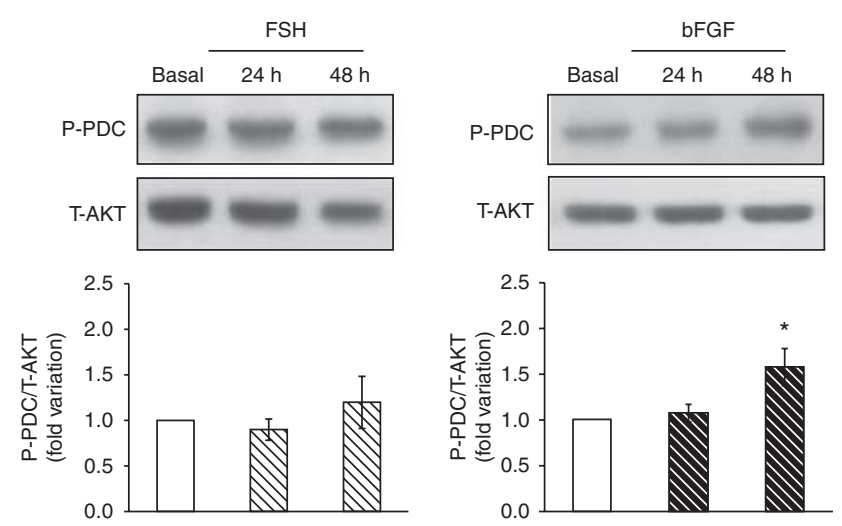

Figure 6 Effects of FSH and bFGF on phosphorylated PDC levels in Sertoli cells. Sertoli cells were stimulated for variable periods ( 24 or $48 \mathrm{~h}$ ) with $100 \mathrm{ng} / \mathrm{ml} \mathrm{FSH}$ or $30 \mathrm{ng} / \mathrm{ml}$ bFGF. Cell extracts were prepared at the designated intervals and utilized for western blot analysis using antibodies specific for phosphorylated PDC (P-PDC) or total AKT (T-AKT). The upper panels show a representative experiment out of three. The lower panels show pooled data of the three independent experiments performed. Results are expressed as mean \pm s.D. of the ratio between P-PDC and T-AKT in each sample $\left({ }^{*} P<0.05\right.$ vs basal).

that can be phosphorylated. All four PDKs phosphorylate site 1 and site 2 while only PDK1 phosphorylates site 3 . It is worth noting that the phosphorylation of a single site results in a complete inactivation of PDC (Korotchkina \& Patel 2001, Rardin et al. 2009). On the other hand, PDP1 and PDP2 can indistinctly dephosphorylate all sites and, as expected, it has been observed that the reactivation of PDC is slower when the three serine residues are phosphorylated (Korotchkina \& Patel 1995, Karpova et al. 2003). In this context, it has been postulated that cells expressing all isoforms of PDKs, which potentially phosphorylate all sites of PDC, can maintain PDC in an inactive form for prolonged periods of time (Korotchkina \& Patel 2001). Supporting this hypothesis, it has been observed that PDC is less active in astrocytes, which express all isoforms of PDKs, than in neurons, which only express PDK2 and PDK4 (Halim et al. 2010). Considering that Sertoli cells express all isoforms of PDKs, it is tempting to speculate that these cells maintain PDC in an inactive form, thus inhibiting the entrance of pyruvate into the tricarboxylic acid cycle. This latter hypothesis gains further support with the pioneering studies on the metabolism of glucose in Sertoli cells. These studies show that Sertoli cells actively metabolize glucose but only a small proportion of this sugar is oxidized via the tricarboxylic acid cycle (Robinson \& Fritz 1981, Grootegoed et al. 1986).

The ability of nutritional states and hormones to regulate PDC activity through the regulation of $P d k s$ and/or Pdps expression has been observed in various cell types. In this respect, it has been observed that $P d k 2$ and $P d k 4$ expression is upregulated and PDC phosphorylated and inactivated in liver during fasting in order to conserve pyruvate for gluconeogenesis (Wu et al. 2000, Jeong et al. 2012). Additionally, it has been observed in different cell types that insulin, secreted in a well-fed state, decreases mRNA levels of $P d k 2$ and $P d k 4$, and increases mRNA levels of $P d p 1$ and $P d p 2$ in order to decrease PDC phosphorylation and consequently direct pyruvate into the tricarboxylic acid cycle (Huang et al. 2002, Abbot et al. 2005, Wang et al. 2009). Our results show that FSH increases Pdk3 and decreases Pdk4 expression and bFGF increases the expression of all $P d k s$. These results indicate that hormones can differentially regulate the expression of Pdks isoforms in Sertoli cells. Additionally, the present study also shows that bFGF, but not FSH, increases the levels of P-PDC in Sertoli cells, suggesting that bFGF promotes PDC inactivation as part of the mechanisms participating in the regulation of lactate production. The relevance of PDKs in the regulation by bFGF of lactate production in Sertoli cells is highlighted by the observation that bFGFstimulated lactate production is diminished in the presence of a PDK inhibitor. It is worth mentioning that in Sertoli cells bFGF increases both LdhA mRNA and $\mathrm{LDH}$ isoenzyme containing four $\mathrm{A}$ subunits (LDH5) levels (Riera et al. 2002). This increase in LDH5, which can convert high amounts of pyruvate to lactate, in conjunction with the above-mentioned regulation of P-PDC levels probably converge to increase lactate production in response to bFGF in Sertoli cells.

As mentioned before, spermatogenesis is an intricate process highly dependent on Sertoli cell function, which is under endocrine (FSH and testosterone) as well as autocrine and paracrine control (Parvinen 1982). It has been observed that several Sertoli cell functions vary with the stage of the spermatogenic cycle (Johnston et al.

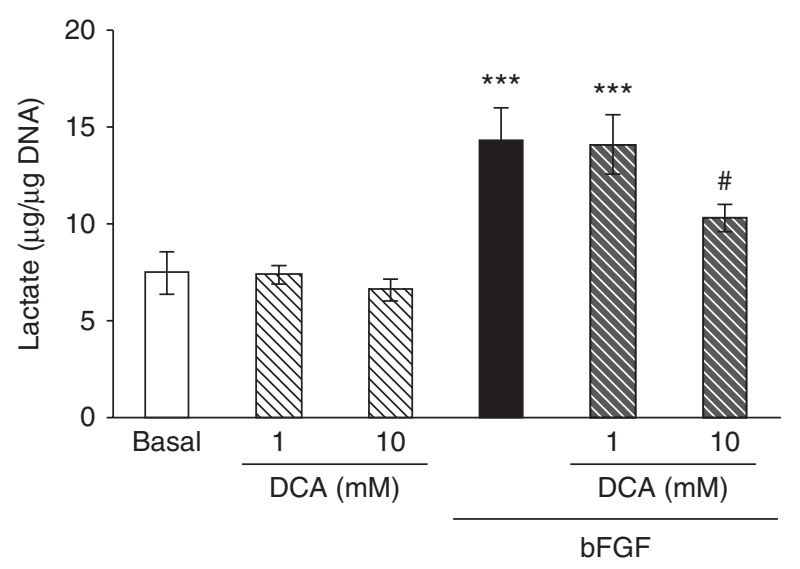

Figure 7 Effect of DCA on bFGF-stimulated lactate production. Sertoli cells were maintained under basal conditions or incubated for $48 \mathrm{~h}$ with $30 \mathrm{ng} / \mathrm{ml}$ bFGF in the absence or presence of DCA ( $1 \mathrm{mM}$ or $10 \mathrm{mM}$ ), a PDK inhibitor. Lactate was determined in the 48-h conditioned media. Results are expressed as mean \pm s.D. of triplicate incubations in one representative experiment out of three ${ }^{* * *} P<0.001$ vs basal; ${ }^{\#} P<0.01$ vs bFGF). 


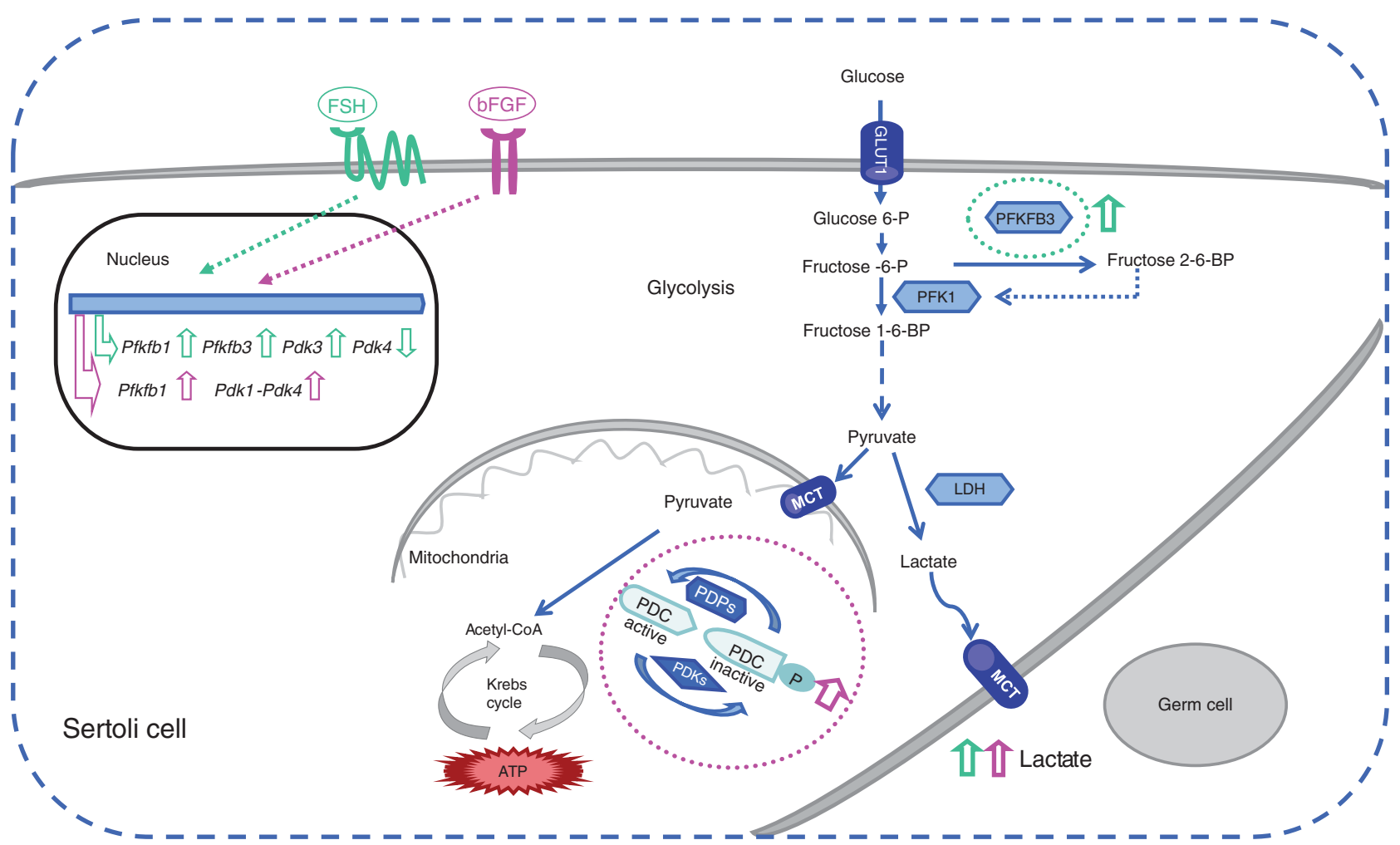

Figure 8 A schematic model of the mechanisms involved in FSH- and bFGF-stimulated lactate production in Sertoli cells. See 'Discussion' for details.

2008). It is known that minimal FSH binding and FSHstimulated cAMP production occurs at stages VI to VII (Kangasniemi et al. 1990). As for bFGF, it has been demonstrated that this peptide is localized predominantly in pachytene spermatocytes and its expression becomes more prominent in stage VII through IX of the cycle (Mayerhofer et al. 1991). Moreover, the expression of bFGF receptors in Sertoli cells was more pronounced in stages I-VIII (Cancilla \& Risbridger 1998). Stagespecific lactate secretion may not be expected, as this metabolic product has been shown to be important for the survival of both spermatocytes and spermatids that are present along all stages of the cycle. Based on the above-mentioned observations, it is tempting to speculate that the coordinated actions of FSH and bFGF throughout the spermatogenic cycle may ensure the provision of adequate lactate levels to maintain the energy requirements of developing germ cells.

In conclusion, the results presented herein, which are summarized in Fig. 8, add new information regarding molecular mechanisms involved in lactate production in Sertoli cells, showing the regulation by hormones of pyruvate availability. The results reinforce the idea that the modulation of metabolic pathways in Sertoli cells is controlled by multiple components, including the action of hormones, the metabolic substrate availability and other endogenous or exogenous factors, which will contribute together to the progression of spermatogenesis to ensure male fertility.

\section{Declaration of interest}

The authors declare that there is no conflict of interest that could be perceived as prejudicing the impartiality of the research reported.

\section{Funding}

This work was supported by the Agencia Nacional de Promoción Científica y Tecnológica (PICT 2011/0677, PICT 2012/0666) and the Consejo Nacional de Investigaciones Cientificas y Técnicas (CONICET) (PIP 2011/187). M N Galardo, S B Cigorraga, S B Meroni and M F Riera are established investigators of CONICET. M Regueira is recipient of CONICET fellowship.

\section{Acknowledgements}

The authors wish to express their gratitude to Dr V Preciado and her staff for helping us with RT-qPCR assay. The technical help of Mercedes Astarloa is gratefully acknowledged.

\section{References}

Abbot EL, McCormack JG, Reynet C, Hassall DG, Buchan KW \& Yeaman SJ 2005 Diverging regulation of pyruvate dehydrogenase kinase isoform gene expression in cultured human muscle cells. FEBS Journal 272 3004-3014. (doi:10.1111/j.1742-4658.2005.04713.x)

Ando M, Uehara I, Kogure K, Asano Y, Nakajima W, Abe Y, Kawauchi K \& Tanaka N 2010 Interleukin 6 enhances glycolysis through expression of 
the glycolytic enzymes hexokinase 2 and 6-phosphofructo-2-kinase/ fructose-2,6-bisphosphatase-3. Journal of Nippon Medical School 77 97-105. (doi:10.1272/jnms.77.97)

Atsumi T, Nishio T, Niwa H, Takeuchi J, Bando H, Shimizu C, Yoshioka N, Bucala R \& Koike T 2005 Expression of inducible 6-phosphofructo-2kinase/fructose-2,6-bisphosphatase/PFKFB3 isoforms in adipocytes and their potential role in glycolytic regulation. Diabetes 54 3349-3357. (doi:10.2337/diabetes.54.12.3349)

Boussouar F \& Benahmed M 2004 Lactate and energy metabolism in male germ cells. Trends in Endocrinology and Metabolism 15 345-350. (doi:10.1016/j.tem.2004.07.003)

Bowker-Kinley MM, Davis WI, Wu P, Harris RA \& Popov KM 1998 Evidence for existence of tissue-specific regulation of the mammalian pyruvate dehydrogenase complex. Biochemical Journal 329 191-196. (doi:10.1042/bj3290191)

Cancilla B \& Risbridger GP 1998 Differential localization of fibroblast growth factor receptor- $1,-2,-3$, and -4 in fetal, immature, and adult rat testes. Biology of Reproduction 58 1138-1145. (doi:10.1095/biolreprod58.5.1138)

Chesney J 2006 6-phosphofructo-2-kinase/fructose-2,6-bisphosphatase and tumor cell glycolysis. Current Opinion in Clinical Nutrition and Metabolic Care 9 535-539. (doi:10.1097/01.mco.0000241661. 15514.fb)

Courtens JL \& Plöen L 1999 Improvement of spermatogenesis in adult cryptorchid rat testis by intratesticular infusion of lactate. Biology of Reproduction 61 154-161. (doi:10.1095/biolreprod61.1.154)

Erkkilä K, Aito H, Aalto K, Pentikäinen V \& Dunkel L 2002 Lactate inhibits germ cell apoptosis in the human testis. Molecular Human Reproduction 8 109-117. (doi:10.1093/molehr/8.2.109)

Galardo MN, Riera MF, Pellizzari EH, Chemes HE, Venara MC, Cigorraga SB \& Meroni SB 2008 Regulation of expression of Sertoli cell glucose transporters 1 and 3 by FSH, IL1 $\beta$, and bFGF at two different time-points in pubertal development. Cell and Tissue Research 334 295-304. (doi:10.1007/s00441-008-0656-y)

Galardo MN, Riera MF, Regueira M, Pellizzari EH, Cigorraga SB \& Meroni SB 2013 Different signal transduction pathways elicited by basic fibroblast growth factor and interleukin $1 \beta$ regulate CREB phosphorylation in Sertoli cells. Journal of Endocrinological Investigation $\mathbf{3 6}$ 331-338. (doi:10.3275/8582)

Galardo MN, Regueira M, Riera MF, Pellizzari EH, Cigorraga SB \& Meroni SB 2014 Lactate regulates rat male germ cell function through reactive oxygen species. PLOS ONE 9 e88024. (doi:10.1371/journal. pone.0088024)

Gnessi L, Fabbri A \& Spera G 1997 Gonadal peptides as mediators of development and functional control of the testis: an integrated system with hormones and environment. Endocrine Reviews 18 541-609. (doi:10.1210/edrv.18.4.0310)

Gómez M, Navarro-Sabaté A, Manzano A, Duran J, Obach M \& Bartrons R 2009 Switches in 6-phosphofructo-2-kinase isoenzyme expression during rat sperm maturation. Biochemical and Biophysical Research Communications 387 330-335. (doi:10.1016/j.bbrc.2009. $07.021)$

Grootegoed JA, Oonk RB, Jansen R \& van der Molen HJ 1986 Metabolism of radiolabelled energy-yielding substrates by rat Sertoli cells. Journal of Reproduction and Fertility 77 109-118. (doi:10.1530/jrf. $0.0770109)$

Gualtieri AF, Mazzone GL, Rey RA \& Schteingart HF 2009 FSH and bFGF stimulate the production of glutathione in cultured rat Sertoli cells. International Journal of Andrology 32 218-225. (doi:10.1111/j.13652605.2007.00836.x)

Gudi R, Bowker-Kinley MM, Kedishvili NY, Zhao Y \& Popov KM 1995 Diversity of the pyruvate dehydrogenase kinase gene family in humans. Journal of Biological Chemistry 270 28989-28994. (doi:10.1074/jbc. 270.48.28989)

Halim ND, McFate T, Mohyeldin A, Okagaki P, Korotchkina LG, Patel MS, Jeoung NH, Harris RA, Schell MJ \& Verma A 2010 Phosphorylation status of pyruvate dehydrogenase distinguishes metabolic phenotypes of cultured rat brain astrocytes and neurons. Glia 58 1168-1176. (doi:10.1002/glia.20996)

Han IS, Sylvester SR, Kim KH, Schelling ME, Venkateswaran S, Blanckaert VD, McGuinness MP \& Griswold MD 1993 Basic fibroblast growth factor is a testicular germ cell product which may regulate Sertoli cell function. Molecular Endocrinology 7 889-897. (doi:10.1210/mend. 7.7.8413313)

Holness MJ \& Sugden M 2003 Regulation of pyruvate dehydrogenase complex activity by reversible phosphorylation. Biochemical Society Transactions 31 1143-1151. (doi:10.1042/BST0311143)

Huang B, Gudi R, Wu P, Harris RA, Hamilton J \& Popov KM 1998 Isoenzymes of pyruvate dehydrogenase phosphatase. DNA-derived amino acid sequences, expression, and regulation. Journal of Biological Chemistry 273 17680-17688. (doi:10.1074/jbc.273.28.17680)

Huang B, Wu P, Bowker-Kinley MM \& Harris RA 2002 Regulation of pyruvate dehydrogenase kinase expression by peroxisome proliferatoractivated receptor- $\alpha$ ligands, glucocorticoids, and insulin. Diabetes 51 276-283. (doi:10.2337/diabetes.51.2.276)

Hue L \& Rider MH 1987 Role of fructose 2,6-bisphosphate in the control of glycolysis in mammalian tissues. Biochemical Journal 245 313-324. (doi:10.1042/bj2450313)

Jeong JY, Jeoung NH, Park KG \& Lee I 2012 Transcriptional regulation of pyruvate dehydrogenase kinase. Diabetes \& Metabolism Journal 36 328-335. (doi:10.4093/dmj.2012.36.5.328)

Johnston DS, Wright WW, Dicandeloro P, Wilson E, Kopf GS \& Jelinsky SA 2008 Stage-specific gene expression is a fundamental characteristic of rat spermatogenic cells and Sertoli cells. PNAS 105 8315-8320. (doi:10. 1073/pnas.0709854105)

Jutte NH, Grootegoed JA, Rommerts FF \& van der Molen HJ 1981 Exogenous lactate is essential for metabolic activities in isolated rat spermatocytes and spermatids. Journal of Reproduction and Fertility $6 \mathbf{2}$ 399-405. (doi:10.1530/jrf.0.0620399)

Kangasniemi M, Kaipia A, Mali P, Toppari J, Huhtaniemi I \& Parvinen M 1990 Modulation of basal and FSH-dependent cyclic AMP production in rat seminiferous tubules staged by an improved transillumination technique. Anatomical Record 227 62-76. (doi:10.1002/ar.1092270108)

Karpova T, Danchuk S, Kolobova E \& Popov KM 2003 Characterization of the isozymes of pyruvate dehydrogenase phosphatase: implications for the regulation of pyruvate dehydrogenase activity. Biochimica et Biophysica Acta 1652 126-135. (doi:10.1016/j.bbapap.2003.08.010)

Kolobova E, Tuganova A, Boulatnikov I \& Popov KM 2001 Regulation of pyruvate dehydrogenase activity through phosphorylation at multiple sites. Biochemical Journal 358 69-77. (doi:10.1042/bj3580069)

Korotchkina LG \& Patel MS 1995 Mutagenesis studies of the phosphorylation sites of recombinant human pyruvate dehydrogenase. Site-specific regulation. Journal of Biological Chemistry 270 14297-14304. (doi:10. 1074/jbc.270.24.14297)

Korotchkina LG \& Patel MS 2001 Site specificity of four pyruvate dehydrogenase kinase isoenzymes toward the three phosphorylation sites of human pyruvate dehydrogenase. Journal of Biological Chemistry 276 37223-37229. (doi:10.1074/jbc.M103069200)

Le Magueresse-Battistoni B, Pernod G, Sigillo F, Kolodié L \& Benahmed M 1998 Plasminogen activator inhibitor-1 is expressed in cultured rat Sertoli cells. Biology of Reproduction 59 591-598. (doi:10.1095/ biolreprod59.3.591)

Lu CW, Lin SC, Chen KF, Lai YY \& Tsai SJ 2008 Induction of pyruvate dehydrogenase kinase- 3 by hypoxia-inducible factor-1 promotes metabolic switch and drug resistance. Journal of Biological Chemistry 283 28106-28114. (doi:10.1074/jbc.M803508200)

Marsin AS, Bouzin C, Bertrand L \& Hue L 2002 The stimulation of glycolysis by hypoxia in activated monocytes is mediated by AMP-activated protein kinase and inducible 6-phosphofructo-2-kinase. Journal of Biological Chemistry 277 30778-30783. (doi:10.1074/jbc.M205213200)

Mayerhofer A, Russell L, Grothe C, Rudolf M \& Gratzl M 1991 Presence and localization of a $30-\mathrm{kDa}$ basic fibroblast growth factor-like protein in rodent testes. Endocrinology 129 921-924. (doi:10.1210/endo129-2-921)

McFate T, Mohyeldin A, Lu H, Thakar J, Henriques J, Halim ND, Wu H, Schell MJ, Tsang TM, Teahan O et al. 2008 Pyruvate dehydrogenase complex activity controls metabolic and malignant phenotype in cancer cells. Journal of Biological Chemistry 283 22700-22708. (doi:10.1074/ jbc.M801765200)

Meroni SB, Riera MF, Pellizzari EH \& Cigorraga SB 2002 Regulation of rat Sertoli cell function by $\mathrm{FSH}$ : possible role of phosphatidylinositol 3-kinase/protein kinase B pathway. Journal of Endocrinology 174 195-204. (doi:10.1677/joe.0.1740195) 
Mita M \& Hall PF 1982 Metabolism of round spermatids from rats: lactate as the preferred substrate. Biology of Reproduction 26 445-455. (doi:10. 1095/biolreprod26.3.445)

Mita M, Price JM \& Hall PF 1982 Stimulation by follicle-stimulating hormone of synthesis of lactate by Sertoli cells from rat testis. Endocrinology 110 1535-1541. (doi:10.1210/endo-110-5-1535)

Moon JS, Jin WJ, Kwak JH, Kim HJ, Yun MJ, Kim JW, Park SW \& Kim KS 2011 Androgen stimulates glycolysis for de novo lipid synthesis by increasing the activities of hexokinase 2 and 6-phosphofructo-2kinase/fructose-2,6-bisphosphatase 2 in prostate cancer cells. Biochemical Journal 433 225-233. (doi:10.1042/BJ20101104)

Newington J, Pitts A, Chien A, Arseneault R, Schubert D \& Cumming R 2011 Amyloid $\beta$ resistance in nerve cell lines is mediated by the Warburg effect. PLOS ONE 6 e19191. (doi:10.1371/journal.pone.0019191)

Novellasdemunt L, Obach M, Millán-Ariño L, Manzano A, Ventura F, Rosa JL, Jordan A, Navarro-Sabate A \& Bartrons R 2012 Progestins activate 6-phosphofructo-2-kinase/fructose-2,6-bisphosphatase 3 (PFKFB3) in breast cancer cells. Biochemical Journal 442 345-356. (doi:10.1042/ BJ20111418)

Oliveira PF, Martins AD, Moreira AC, Cheng CY \& Alves MG 2015 The Warburg effect revisited-lesson from the Sertoli cell. Medicinal Research Reviews 35 126-151. (doi:10.1002/med.21325)

Parvinen M 1982 Regulation of the seminiferous epithelium. Endocrine Reviews 3 404-417. (doi:10.1210/edrv-3-4-404)

Rardin MJ, Wiley SE, Naviaux RK, Murphy AN \& Dixon JE 2009 Monitoring phosphorylation of the pyruvate dehydrogenase complex. Analytical Biochemistry 389 157-164. (doi:10.1016/j.ab.2009.03.040)

Regueira M, Riera MF, Galardo MN, Pellizzari EH, Cigorraga SB \& Meroni SB 2014 Activation of PPAR $\alpha$ and PPAR $\beta / \delta$ regulates Sertoli cell metabolism. Molecular and Cellular Endocrinology 382 271-281. (doi:10.1016/j.mce.2013.10.006)

Rider MH, Bertrand L, Vertommen D, Michels PA, Rousseau GG \& Hue L 2004 6-phosphofructo-2-kinase/fructose-2,6-bisphosphatase: head-tohead with a bifunctional enzyme that controls glycolysis. Biochemical Journal 381 561-579. (doi:10.1042/BJ20040752)

Riera MF, Meroni SB, Gomez GE, Schteingart HF, Pellizzari EH \& Cigorraga SB 2001 Regulation of lactate production by FSH, IL1 $\beta$ and TNF $\alpha$ in rat Sertoli cells. General and Comparative Endocrinology 122 88-97. (doi:10.1006/gcen.2001.7619)

Riera MF, Meroni SB, Schteingart HF, Pellizzari EH \& Cigorraga SB 2002 Regulation of lactate production and glucose transport as well as of glucose transporter 1 and lactate dehydrogenase A mRNA levels by basic fibroblast growth factor in rat Sertoli cells. Journal of Endocrinology 173 335-343. (doi:10.1677/joe.0.1730335)

Robinson R \& Fritz I 1981 Metabolism of glucose by Sertoli cells in culture. Biology of Reproduction 24 1032-1041. (doi:10.1095/ biolreprod24.5.1032)
Ros S \& Schulze A 2013 Balancing glycolytic flux: the role of 6-phosphofructo-2-kinase/fructose 2,6-bisphosphatases in cancer metabolism. Cancer \& Metabolism 1 8. (doi:10.1186/2049-3002-1-8)

Rowles J, Scherer S, Xi T, Majer M, Nickle DC, Rommens JM, Popov KM, Harris RA, Riebow NL, Xia J et al. 1996 Cloning and characterization of PDK4 on 7q21.3 encoding a fourth pyruvate dehydrogenase kinase isoenzyme in human. Journal of Biological Chemistry 271 22376-22382. (doi:10.1074/jbc.271.37.22376)

Sakakibara R, Kato M, Okamura N, Nakagawa T, Komada Y, Tominaga N, Shimojo M \& Fukasawa M 1997 Characterization of a human placental fructose-6-phosphate, 2-kinase/fructose-2,6-bisphosphatase. Journal of Biochemistry 122 122-128. (doi:10.1093/oxfordjournals. jbchem.a021719)

Schteingart HF, Meroni SB, Canepa DF, Pellizzari EH \& Cigorraga SB 1999 Effects of basic fibroblast growth factor and nerve growth factor on lactate production, $\gamma$-glutamyl transpeptidase and aromatase activities in cultured Sertoli cells. European Journal of Endocrinology/European Federation of Endocrine Societies 141 539-545. (doi:10.1530/eje.0. 1410539)

Smith EP, Hall SH, Monaco L, French FS, Wilson EM \& Conti M 1989 A rat Sertoli cell factor similar to basic fibroblast growth factor increased c-fos messenger ribonucleic acid in cultured Sertoli cells. Molecular Endocrinology 3 954-961. (doi:10.1210/mend-3-6-954)

Sugden M \& Holness MJ 2006 Mechanisms underlying regulation of the expression and activities of the mammalian pyruvate dehydrogenase kinases. Archives of Physiology and Biochemistry 112 139-149. (doi:10. 1080/13813450600935263)

Wang Z, Iwasaki Y, Zhao LF, Nishiyama M, Taguchi T, Tsugita M, Kambayashi M, Hashimoto K \& Terada Y 2009 Hormonal regulation of glycolytic enzyme gene and pyruvate dehydrogenase kinase/phosphatase gene transcription. Endocrine Journal 56 1019-1030. (doi:10.1507/ endocrj.K09E-178)

Warburg O, Wind F \& Negelein E 1927 The metabolism of tumors in the body. Journal of General Physiology 8 519-530. (doi:10.1085/jgp. 8.6.519)

Wu P, Blair PV, Sato J, Jaskiewicz J, Popov KM \& Harris RA 2000 Starvation increases the amount of pyruvate dehydrogenase kinase in several mammalian tissues. Archives of Biochemistry and Biophysics 381 1-7. (doi:10.1006/abbi.2000.1946)

Received 11 May 2015

First decision 5 June 2015

Revised manuscript received 30 June 2015

Accepted 29 July 2015 